\title{
OIL OF PANDAN KELAPA HUTAN (Pandanus jiulianettii Martelli): PHYSICOCHEMICAL PROPERTIES, TOTAL PHENOLS, TOTAL CAROTENE, VITAMIN E AND ANTIOXIDANT ACTIVITY
}

\author{
MINYAK PANDAN KELAPA HUTAN (Pandanus j iulianettii Martelli): SIFAT \\ FISIKOKIMIA, TOTAL FENOL, TOTAL KAROTEN, VITAMIN E DAN \\ AKTIVITAS ANTIOKSIDAN
}

\author{
Lisye Iriana Zebua And Vita Purnamasari* \\ Departement of Biology, Faculty of Mathematic and Natural Science, Cenderawasih University, \\ Kampus Baru, UNCEN, Waena, J ayapura, Papua \\ *Email: purnamasari.vita@yahoo.co.id
}

Diterima 7 Mei 2017. Disetujui 13 Oktober 2017

\section{INTISARI}

Tumbuhan pandan merupakan salah satu tanaman penting di Papua dan Papua New Guinea. Secara tradisional tumbuhan pandan digunakan oleh masyarakat untuk berbagai keperluan sehari-hari, mulai dari penyedap makanan, obat hingga keperluan upacara keagamaan. Buah pandan kelapa hutan (Pandanus jiulianettii Martelli) adalah salah satu jenis kelompok Pandanus yang telah dimanfaatkan secara turun temurun oleh masyarakat yang tinggal di dataran tinggi Papua dan Papua New Guinea sebagai bahan makanan. Penelitian ini bertujuan menentukan sifat fisikokimia, total fenol, total karoten, vitamin E dan aktivitas antioksidan minyak pandan kelapa (P. jiulianettii Martelli) yang diekstrak menggunakan wajan aluminium. Sifat fisikokimia yang dianalisis adalah bilangan iod, bilangan penyabunan, kadar asam lemak bebas, bilangan asam dan bilangan peroksida. Total fenol, total karoten dan vitamin E masing-masing diukur menggunakan metode Folin-Ciocalteu, metode spektrofotometer dan metode kolorimetri. Aktifitas antioksidan diukur menggunakan metode DPPH. Hasil penelitian menunjukkan minyak pandan kelapa mempunyai berat jenis 1,00059, bilangan iod 65,87 g/ $100 \mathrm{gr}$, bilangan penyabunan 201,28 mg/ g, kadar asam lemak bebas $0,91 \%$, bilangan asam 4,26\%, bilangan peroksida 5,64 meq/ kg dan total karoten 2,75 $\mu \mathrm{g} / \mathrm{g}$. Kandungan total fenol, total karoten masing-masing adalah 48.55 ppm, $2.75 \mu \mathrm{g} / \mathrm{g}$ and $5.0303 \mathrm{mg} / 100 \mathrm{~g}$. Hasil pengukuran antioksidan IC50 menunjukkan nilai 45,83 mg/ mL.

Kata kunci: Pandanus Jiulianettii, karakter fisikokimia minyak, total fenol, DPPH method.

\begin{abstract}
Pandanus plant is one of the important plant in Papua and Papua New Guinea. Traditionally pandanus plant is used by local people for lots of daily activities and daily needs, start from food flavoring, medicine, to religious ceremony needs. Pandan kelapa hutan fruits (P. jiulianettii Martelli.) is one of a kind of pandanus that been used from generation to generation the highlands of Papua and Papua New Guinea for the food ingredients. This research aims to determine the physicochemical properties, total phenol, total carotene, vitamin $\mathrm{E}$ and antioxidant activities of the forest coconut pandan oil (P. jiulianettii Martelli.) extracted using an aluminum pan. Physicochemical character that been analyzed is specific gravity, iod value, saponification value, free fatty acid content, acid value and peroxide value. Total phenol, total carotene and vitamin $\mathrm{E}$ measured respectively using Folin-Ciocalteu method, spectrophotometry method and colorimetric methods. Antioxidant activities is measured using a method that called DPPH. The result shows the pandan coconut oil has 1,00059 of specific gravity, $65.87 \mathrm{~g} / 100 \mathrm{gr}$ of iod, $201,28 \mathrm{mg} / \mathrm{g}$ of saponification, $4.26 \%$ of acid and 5.64 $\mathrm{Meq} / \mathrm{kg}$ of peroxide. The content of total phenols, total carotene and vitamin E respectively are $48.55 \mathrm{ppm}$, $2.75 \mathrm{\mu g} / \mathrm{g}$ and $5.0303 \mathrm{mg} / 100 \mathrm{~g}$. The antioxidant IC50 measuring result shows the value is $45.83 \mathrm{mg} / \mathrm{mL}$.
\end{abstract}

Keywords: Pandanus jiulianettii, antioxidant, total phenols. 


\section{BACKGROUND}

Pandanus plant has been used for a long time by the people who live in the highlands of Papua and Papua New Guinea, one of them is pandan kelapa hutan that consist from a variety of cultivars. Those people who lives on mountain areas of Jayawijaya know and consume pandan kelapa hutan as daily food and also as alternative if the sweet potatoes are failed to harvest. Sweet potatoes are the main food for the people who live at Jayawijaya Mountains (Kogoya, 2012).

Pandan kelapa hutan (P. jiulianettii Martelli.) is one of a variety of pandan which is the fruit was been used as a food. Not just at Papua Mountains, but also at Papua New Guinea mountains (Stone, 1982; Rose, 1982). Tribe Dani and tribe Lani respectively know pandan kelapa hutan with local name tuke and woromo. According to those who live in J ayawijaya, the taste of P. jiulianettii Martelli is savory and the scent is like a coconut. The kernel of this fruit can be eaten raw or cooked. The way to cook is burning it in hot ashes or steaming in burn stone (Milliwen, 1992).

The utilization of fat and oil as food material or in food processing need to be considered the physicochemical character that desirable. That character is being the basic of selection of fat or oil source at the time will be used as food materials or in food processing (Kusnandar, 2010).

Chemical composition of pandan kelapa hutan fruit (P. jiulianettii Martelli.) is dominated by $47 \%$ fat, it means potentially become a source of oil fat (Kogoya et al, 2014). But, there is no information about physicochemical character antioxidant capacity of pandan kelapa hutan oil. This research aims to know how to obtained physicochemical character such as iod value, saponification value, acid value, free fatty acid content, peroxide value, carotene, and antioxidant capacity from pandan kelapa hutan oil.

\section{MATERIAL AND METHODS}

\section{Plant materials}

Samples were from a fruit of pandan kelapa hutan (P. jiulianettii Martelli.) that mature and the hood is still wrapped (Fig. 1a). Samples obtained from Lanny Jaya district and transported to Biology Laboratorium, Cenderawasih University. The fruit of pandan kelapa hutan has separated from the hood, then the protective layer of the fruit got cracked to get the endosperm inside. The colour of endosperm is white. The endosperm obtained is then extracted to get the pandan kelapa hutan oil (Fig.1b).

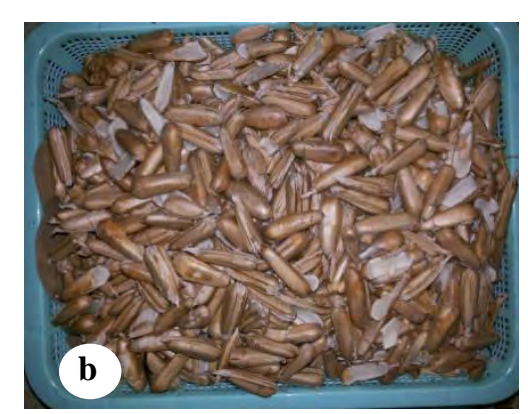

Figure 1. a and b. Pandanus jiulianettii Martelli. a. The fruits mature; b. Endosperms (white colour).

The ingredients that used iodine value, saponification value, acid, free fatty acid content, peroxide value, carotene and antioxidant activity is iodium, $\mathrm{KOH}, \mathrm{n}$-hexane, ethanol, eter, phenolphthalein indicator, $\mathrm{HCl}, \mathrm{KI}, \mathrm{Na}_{2} \mathrm{~S}_{2} \mathrm{O}_{3}$, starch indicator, $\mathrm{NaOH}, \mathrm{Br}$, acetic acid glacial, diethyl ether, $\mathrm{DPPH}$, methanol and aquadest.

\section{Oil Extraction of forest coconut fruits}

Oil of pandan kelapa hutan fruits extracted using the method of wet rendering with aluminum pan. Endosperm of pandan kelapa hutan fruit (P. jiulianettii Martelli.) that has been separated from the protective layer of the fruit washed with water flowing. Endosperm then in blender with the addition of water 1:1. Coconut milk can be obtained then heated at a temperature between $60^{\circ} \mathrm{C}-70^{\circ} \mathrm{C}$ until we can obtain the oil. Then the oil is separated from dregs of pandan kelapa hutan milk using centrifuge. The oil that obtained is stored in a dark color bottle before used to determine the nature of physicochemical and antioxidant capacity.

\section{Determination of iodine value, saponification value, acid value, peroxide value, and levels of free fatty acids.}

Iodine value of pandan kelapa hutan oil determined by Hanus method (AOAC 920.158, 2011). 
Briefly, 0.1-0.5 $\mathrm{g}$ of oil was placed in a erlenmeyer and dissolved in $30 \mathrm{~mL} \mathrm{CHCl} 3$. Added $25 \mathrm{~mL}$ Hanus $\mathrm{I}_{2}$ solution with pipet and let stand $30 \mathrm{~min}$ in the dark with shaking occasionally. Added with $10 \mathrm{~mL}$ 15\% KI solution and $100 \mathrm{~mL}$ aquadest thus shaked thoroughly. The solution titrated with $0,1 \mathrm{M} \mathrm{Na} \mathrm{S}_{2} \mathrm{O}_{3}$ with constant shaking until yellow solution turns almost colourless. Added few drops starch indicator and continue titration until blue entirely dissapears. A blank was made the same way without the sample. The amount of titration of $\mathrm{Na}_{2} \mathrm{~S}_{2} \mathrm{O}_{3}$ recorded. Number of $\mathrm{mL} 0,1 \mathrm{M} \mathrm{Na} \mathrm{S}_{2} \mathrm{O}_{3}$ required by blank minus $\mathrm{mL}$ used in determination sample gives $\mathrm{Na}_{2} \mathrm{~S}_{2} \mathrm{O}_{3}$ equivalent of $\mathrm{I}_{2}$ (Hanus solution) absorbed by the oil. Calculated \% by weight of $\mathrm{I}_{2}$ absorbed.

Saponification value of pandan kelapa hutan oil determined by titrimetric methods (AOAC 920.160, 2011). Acurately weighed $5 \mathrm{~g}$ filtered oil into erlenmeyer and added $50 \mathrm{~mL}$ alcoholic $\mathrm{KOH}$ solution. Connected flask with air condensor and boiled until fat was completely saponified (ca $30 \mathrm{~min}$ ). Cooled and titrated with $0,5 \mathrm{M} \mathrm{HCl}$ using indicator phenolphthalein. Conducted blank determination along with that on test portion. Calculated saponification number ( $\mathrm{mg} \mathrm{KOH}$ required to saponify $1 \mathrm{~g}$ fat $)=28.05(\mathrm{~B}-\mathrm{S}) / \mathrm{g}$ oil. $\mathrm{B}=\mathrm{mL} 0.5 \mathrm{M} \mathrm{HCl}$ required by blankand $\mathrm{S}=\mathrm{mL} 0.5 \mathrm{HCl}$ required test portion.

Acid value of pandan kelapa hutan oil determined by titration method (AOAC 969.17, 2011). Weighed 5$10 \mathrm{~g}$ oil into 250-300 mL erlenmeyer. Added 50-100 $\mathrm{mL}$ alcohol-ether mixture and phenolphthalein solution. The solution titrated with $0,1 \mathrm{~N}$ alcoholic $\mathrm{KOH}$ until permanent faint pink appears and persists for $\geq 10 \mathrm{~s}$. Acid value $=\mathrm{mL}$ alcohol solution $\mathrm{X}$ normality alcoholic $\mathrm{KOH}$ solution X 56.1/g sample.

Free fatty acids content determined by titration methods (AOAC 940.28, 2011). Weighted $7.05 \mathrm{~g}$ oil into $250 \mathrm{~mL}$ flask. Add $50 \mathrm{~mL}$ of alcohol previously neutralized by adding $2 \mathrm{~mL}$ phenolphthalein solution and enough $0.1 \mathrm{M} \mathrm{NaOH}$ to produce faint permanent pink. The oilition titrated with $0.25 \mathrm{M} \mathrm{NaOH}$, then vigorous shaking until permanent faint pink appears and persists $\geq 1 \mathrm{~min}$. Report as percent free fatty acids expressed as oleic acid; $\mathrm{mL} 0.25 \mathrm{M} \mathrm{NaOH}$ used in titration corresponds to this percent.

Peroxide value of pandan kelapa hutan oil determined with titration method (AOAC 965.33, 2011). Weighed $5 \pm 0.05 \mathrm{~g}$ oil into $250 \mathrm{~mL}$ erlenmeyer. Added $30 \mathrm{~mL} \mathrm{CH}_{3} \mathrm{COOH}-\mathrm{CHCl}_{3}$ and swirl to dissolve. Added $0.5 \mathrm{~mL}$ saturated $\mathrm{KI}$ solution, let stand with occasional shaking $1 \mathrm{~min}$ and added $30 \mathrm{~mL}$ aquadest. Slowly titrated with $0.1 \mathrm{M} \mathrm{Na} \mathrm{Na}_{2} \mathrm{O}_{3}$ with vigorous shaking until yellow was almost gone. Added ca $0.5 \mathrm{~mL} 1 \%$ starch solution and continue titration, shaking vigorously to release all $\mathrm{I}_{2}$ from $\mathrm{CHCl}_{3}$ layer, until blue just disappears. Determination of blank conducted daily. Peroxide value (milliequivalent peroxide $/ \mathrm{kg}$ oil) $=$ SX MX 1000/g test portion, where $\mathrm{S}=\mathrm{mL} \mathrm{Na} 2 \mathrm{~S}_{2} \mathrm{O}_{3}$ (blank corrected) and $\mathrm{M}=$ molarity $\mathrm{Na}_{2} \mathrm{~S}_{2} \mathrm{O}_{3}$ solution.

\section{Determination of total carotenoid}

Total carotene determined with spectrophotometry method (AOAC, 2011). Approximately $15 \mathrm{~g}$ of the samples, plus $3 \mathrm{~g}$ of celite were weighed in a mortar on a digital balance. For the carotenoid extraction, successive additions of $25 \mathrm{~mL}$ of acetone were made to obtain a paste, which was transferred into a sintered funnel $(5 \mu \mathrm{m})$ coupled to a $250 \mathrm{~mL}$ Buchner flask and filtered under vacuum. This procedure was repeated three times or until the sample became colorless. The extract obtained was transferred to a $500 \mathrm{~mL}$ separatory funnel containing $40 \mathrm{~mL}$ of petroleum ether. The acetone was removed through the slow addition of ultrapure water to prevent emulsion formation. The aqueous phase was discarded. This procedure was repeated four times until no residual solvent remained. Then, the extract was transferred through a funnel to a $50 \mathrm{~mL}$ volumetric flask containing $15 \mathrm{~g}$ of anhydrous sodium sulfate. The volume was made up by petroleum ether, and the samples were read at $450 \mathrm{~nm}$. The total carotenoid content was calculated using the following formula:

$$
\text { Carotenoids content }(\boldsymbol{\mu g} / \mathrm{g})=\frac{\mathrm{A} \times \mathrm{V}(\mathrm{mL}) \times 104}{A 1 \mathrm{~cm} 1 \% \times \mathrm{P}(\mathrm{g})}
$$

where $\mathrm{A}=$ =Absorbance; $\mathrm{V}=$ Total extract volume; $\mathrm{P}$ = sample weight; $\mathrm{A}_{1 \mathrm{~cm}}$ 1\% $=2592$ ( $\boldsymbol{\beta}$-carotene Extinction Coefficient in petroleum ether).

\section{Determination of total phenol}

The total phenol in the pandan kelapa hutan oil was determined by using Folin-Ciocalteu reagent. The phenol component was extracted by dissolving $0,1 \mathrm{~g}$ oil of forest coconut pandan in $1 \mathrm{~mL}$ of $80 \%$ methanol, centrifuging at $1100 \mathrm{rpm}$ for $10 \mathrm{~min}$ then collecting the filtrate. The extraction process was repeated four times (Seneviratne et al., 2009) and the filtrate collected was added with $80 \%$ methanol to $5 \mathrm{~mL}$. Measurement of total phenols was done by adding 0.5 $\mathrm{mL}$ Folin-Ciocalteu reagen to the $1 \mathrm{~mL}$ oil of forest coconut pandan fruit and the content mixed thoroughly. After $5 \mathrm{~min}, 1 \mathrm{~mL}$ of $5 \% \mathrm{Na}_{2} \mathrm{CO}_{3}$ and $5 \mathrm{~mL}$ deionized water was added then the mixture was allowed to stand for $1 \mathrm{~h}$ at normal temperature. Absorbance was measured by spectrophotometry at a 
wavelength of $745 \mathrm{~nm}$. A blank was made with the same procedure without sample. Gallic acid was used as the standart for the calibration curve.

\section{Determination of vitamin $\mathbf{E}$}

Vitamin $\mathrm{E}$ of pandan kelapa hutan oil determinated by colorimetric method (AOAC 971.30, 2011). Briefly, $1 \mathrm{~g}$ oil of forest coconut pandan, $10 \mathrm{~mL}$ absolut alcohol and $20 \mathrm{~mL}, 1 \mathrm{M}$ alcoholic sulphuric acid was reflux for $45 \mathrm{~min}$ in a condenser and cooled fo $15 \mathrm{~min}$. Unsaponifiable matter in the mixture was extracted with dimethyl ether. The extracts evaporated at a low temperature and the residues obtained were dissolved in $10 \mathrm{~mL}$ absolute alcohol. Absolute alcohol $(5 \mathrm{~mL})$ and $1 \mathrm{~mL} \mathrm{HNO}_{3}$ was added to aliquots of the sample and standart (0.3-3.0 mg vitamin E). The mixture was evaporated in a water bath at $90^{\circ} \mathrm{C}$ for $3 \mathrm{~min}$ from the time the alcohol starting boiling. A series of standard solutions of known concentration were determined with reference to their absorbance from which average was recorded. It absorbance was measured at $290 \mathrm{~nm}$ using a spectrophotometer against a blank containing $5 \mathrm{~mL}$ absolute alcohol and $1 \mathrm{~mL} \mathrm{HNO}_{3}$ and treated in similar manner. The vitamin E content was calculated using the following formula:

$$
\text { Vitamin } \mathrm{E}(\mu \mathrm{g} / 100 \mathrm{~g})=\frac{\text { absorbance of sample X dilution factor X gradient }}{\text { weight sample }}
$$

\section{Measurement of 2,2-diphenil 1-picrylhydrazyl (DPPH)-radical scavenging activity}

Radical scavenging activity of pandan kelapa hutan oil determinated by DPPH method. 2,2-diphenyl 1picrylhydrazyl (DPPH) used to source of free radical. DPPH radical scavenging activity was assessed according to Kikuzaki et al. (2002). In this test 50 $\mu$ of pandan kelapa hutan oil with different concentration, added with $1 \mathrm{~mL}$ solution $0,4 \mathrm{mM} \mathrm{DPPH}$, methanol

Percentage $(\%)$ cleaning radical DPPH = and $5 \mathrm{~mL}$ of methanol. Mixture solution and forest coconut pandan oil then mixed using vortex and left it for 30 minutes at room temperature in the dark room. Measurement scavenging effect on the DPPH radical done using spectrophotometer on the wavelength of $517 \mathrm{~nm}$. The radical scavenging activity was expressed as the radical scavenging percentage using the following equation:

$$
\left(\mathrm{I}-\frac{A s}{A c}\right) \times 100
$$

Where, $\mathrm{AS}=$ Absorbance samples, $\mathrm{AC}=$ absorbance control, Control $=\mathrm{DPPH}$ solution without sample (forest coconut pandan oil).

Value $\mathrm{IC}_{50}$ is the number of samples (antioxidant) required for $50 \%$ scavenging of DPPH radical and calculated from the graph describe the relationship scavenging activity the radical to the number of samples. The DPPH solution without sample solution of pandan kelapa hutan oil used as a control.

\section{RESULTS}

\section{Physicochemical character}

The determination of iodine value, saponification value, acids value, peroxide value and levels of free fatty acids of pandan kelapa hutan oil can be seen in Table 1. The acid value of forest coconut pandan oil represent the free fatty acids present in oil or fat. Saponification value can be used to estimate the molecular weights of fatty acids that compose forest coconut pandan oil. Iodine value indicate unsaturation degree oil or fat (Arumsari et al., 2013). Peroxide value, levels of free fatty acids and acid value is often used as parameter damage of oil or fat (Kusnandar, 2010).

Table 1. Physicochemical characteristic of pandan kelapa hutan oil

\begin{tabular}{lll}
\hline Parameter & Value & Unit \\
\hline Iodine value & 65.87 & $\mathrm{~g} / 100 \mathrm{~g}$ \\
Saponification value & 201.28 & $\mathrm{mg} \mathrm{KOH} / \mathrm{g}$ \\
Acid value & 4.26 & $\%$ \\
Peroxide value & 5.64 & meq O$/ \mathrm{kg}$ \\
Free fatty acid content & 0.91 & $\%$ \\
\hline
\end{tabular}


Total phenol, total carotene, vitamin $\mathrm{E}$ and antioxidant activity of forest coconut pandan oil

The total phenol, total carotene, vitamin E and antioxidant activity content of pandan kelapa hutan oil are shown in Table 2. Total phenol of pandan kelapa hutan oil are $48,55 \mathrm{ppm}$. The way of determination of the level of total phenolic is based on their chemical reducing capacity relative to gallic acid.

Table 2. Total phenol, total carotene, vitamin E and antioxidant activity of forest coconut pandan oil

\begin{tabular}{|c|c|c|c|c|c|c|}
\hline $\begin{array}{l}\text { Pandan } \\
\text { hutan }\end{array}$ & kelapa & $\begin{array}{l}\text { Total phenol } \\
(\mathrm{ppm})\end{array}$ & $\begin{array}{l}\text { Total carotene } \\
(\mu \mathrm{g} / \mathrm{g})\end{array}$ & $\begin{array}{l}\text { Vitamin } \\
(\mathrm{mg} / 100 \mathrm{~g})\end{array}$ & $\begin{array}{l}\text { Antioxidant } \\
\text { IC50 (mg/ g) }\end{array}$ & activity \\
\hline Oila $^{a}$ & & 48.55 & 2.75 & 5.03 & 45.83 & \\
\hline Fruitb & & & 8.42 & 0.46 & & \\
\hline
\end{tabular}

a Primery data

b Kogoya et al. (2014)

Levels of the total carotene contains inside pandan kelapa hutan oil is $2,75 \mu \mathrm{g} / \mathrm{g}$. Carotenoids is pigment fat-soluble. In additions, it works the pigment that make up the colour such is yellow and orange (Fig. 2). Carotenoids is also a compound provitamin A. Carotenoid has many kind of variety in plant, there are $\beta$-carotene, $\alpha$-carotene, $\beta$-kriptoxantin, lutein, and lycopene (Bendich and olson, 1989).

Content of vitamin E of pandan kelapa hutan oil measured as $\alpha$-tokoferol. Oil of pandan kelapa hutan contained $5.0302 \mathrm{mg} / 100 \mathrm{~g}$ a-tocopherol. Vegetable oil are important compounds of source of energy, fatty acids and fat-soluble vitamins such as vitamin A and vitamin $\mathrm{E}$. Tocopherols are natural antioxidants that also present vitamin $\mathrm{E}$ activity, especially $\alpha$ tocopherol (De Greyt and Kellens, 2005).

Measuring the antioxidant activity IC50 (inhibition concentration) 50 of pandan kelapa hutan oil with $\mathrm{DPPH}$ shows the value of $45.83 \mathrm{mg} / \mathrm{g}$. That is to clear $50 \%$ of free radicals DPPH required a pandan kelapa hutan oil with a concentration of $45.83 \mathrm{mg} / \mathrm{g}$.

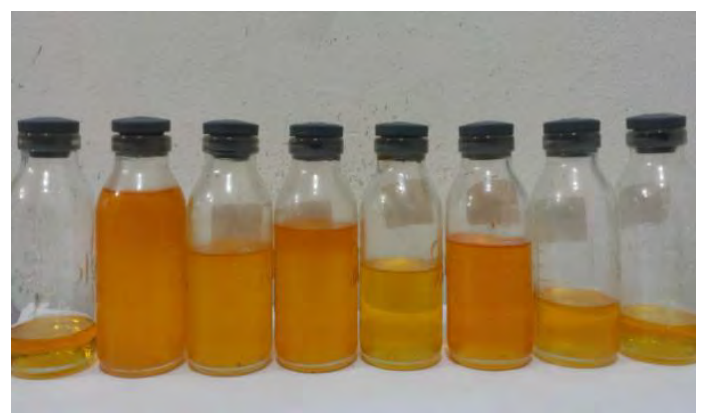

Figure 2. The oil of pandan kelapa hutan

\section{DISCUSSIONS}

Oil yield with wet rendering extraction of pandan kelapa hutan oil is yellow (Figure 2). The colors correspond to the Indonesian National Standard (SNI) 2006 for palm oil colors yellow, orange to red.

The results of the measurement of iodine value of oil palm fruit in the pandan kelapa hutan oil (Table 1) indicates the degree of unsaturated fatty acids that compose the oil. Kogoya et al. (2014) stated that pandan kelapa hutan fruit dominated by palmitic acid $(28,66 \%)$, trans oleic acid $(9,29 \%)$ and stearic acid $(3,77 \%)$ as well as cis oleic acid $(1,84 \%)$. The fatty acid composition of pandan kelapa hutan fruit in accordance with the iodine value of the oil is not too high, however unsaturated fatty acid more dominant.

Saponification value indicates the molecular weight of the oil or fat. The lower the molecular weight, the greater the saponification; the larger molecular weight, the smaller the saponification. Result of determination saponification oil palm fruit in the forest (Table 1) indicates the average triglyceride oil constituent pandan kelapa hutan has a low molecular weight.

Acid value, peroxide value and free fatty acid content is quality parameters for oil or fat. Fatty acid content of pandan kelapa hutan oil is relatively high (Table 1) compared to the standard CPO (maximum fatty acid level of 0.5\%; SNI (2006) and palm oil standard (maximum fatty acid content of $0.3 \%$; SNI (2012). Differences in levels of fatty acid free, indicates the start of the hydrolysis of the pandan kelapa hutan oil that severing of ties between the fatty acid ester and glycerol produce free fatty acids. Hydrolysis can be triggered by the presence of water and lipase activity of fruit (Ngando et al, 2006), which 
may occur during harvesting or during the extraction process. The level of ripeness at the time harvesting indirectly affect the occurrence of hydrolysis.

Salvador et al. (2001) reported that the olive oil produced from olives which is really measured has a high acidity because of the activity of lipase internally, the sensitivity of the pathogen and because of mechanical damage. For it is necessary to overcome postharvest handling and extraction process which can reduce and even suppress the occurrence the hydrolysis. Possibility the start of the hydrolysis on a pandan kelapa hutan oil also indicate woods by value and acid number peroxide number (table 1). Number acid indicates the presence of free fatty acids in the oil of pandan kelapa hutan, while the peroxide value showed the oil oxidation (Kusnandar, 2010).

Oil yield extraction of pandan kelapa hutan fruit contains carotene indicated by the total pigment levels of carotenes (table 1). Carotene is associated with yellow, orange and red in plants and vegetable and is soluble fat (Muchtadi, 2012). Carotene content in the oil of pandan kelapa hutan fruit associated with the color yellow oil produced from the extraction fruit.

The one of important parameters associated with functionality and quality of oil is content of phenolic. Phenolic compounds may contribute to oil flavor and protect the fatty acids from oxidation (Servili and Montedoro, 2002). The total phenol content of pandan kelapa hutan oil (table 2) was lower than that red fruits oil (90-705 ppm) according to Sarungallo et al. (2015).

The content of vitamin $\mathrm{E}$ of pandan kelapa hutan oil (P. jiulianettii) is higher than content of vitamin $E$ of pandan kelapa hutan fruits (table 2). The high variability in the amount of vitamin $E$ in vegetable oil has been widely reported and depends on several factors, such as genetic, agronomic, enviromental, extraction procedural and others (Cimato, 1990; Mousa et al., 1996).

Measurement IC50 pandan kelapa hutan oil (table 1) shows that low antioxidant activity due to scavenging activity $50 \%$ of free radical DPPH required pandan kelapa hutan oil as much forest $45.83 \mathrm{mg} / \mathrm{mL}$. IC50 is concentration of antioxidants that is needed to clear the DPPH radical timed. Low $\mathrm{IC}_{50}$ value indicates high activity of antioxidant, in the other hands high IC50 value indicates low activity of antioxidant (Maisuthisakul et al., 2007). Low antioxidant activity is associated with the total phenol content of forest coconut pandan fruits oil (Table 1).

\section{CONCLUSION}

Oil extraction from pandan kelapa hutan is yellow, and the composition of saturated fatty acids is dominant than unsaturated fatty acid. It also means triglyceride constituent has a low molecular weight. Allegedly began to form free fatty acid in the oil of pandan kelapa hutan by acid value, peroxide value and fatty acid levels free. Pandan kelapa hutan oil contains $48.55 \mathrm{ppm}$ of total phenol, $5.03 \mathrm{mg} / 100 \mathrm{~g}$ of vitamin E, $2.75 \mathrm{\mu g} / \mathrm{g}$ of total carotene and 45.83 $\mathrm{mg} / \mathrm{mL}$ of antioxidant activity $\mathrm{IC}_{50}$.

\section{ACKNOWLEDGEMENT}

Thank you to Ministry of Research, Technology and Higher Education, that funded this research through Competitive Grant Funds in 2015 to 2016.

\section{REFERENCES}

Arumsari, N.I., S. Riyanto and Rohman. 2013. Some physico-chemical properties of red fruit oil (Pandanus conoideus Lam) from hexane and chloroform fractions. J. Food Pharma. Sci.1: 30-34.

Association of Analytical Chemists. 2011. Official Methods of Analysis. 16th ed. Association of Analytical Chemists. Washington, DC, USA.

Bendich, A. and J .A. Olson. 1989. Biological action of carotenoids. FASEB J. 3:1927-1932.

Cimato, A. 1990. Effect of agronomic factor on vingin olive oil quality. Olivae 31: 20-31.

De Greyt, W. and M. Kellens. 2005. Deodorization. In F. Shahidi (Ed). Bailey's industrial oil and fat product (Vol. 5, pp. 341-383). New York: John Wiley and Son. $6^{\text {th }}$ ed.

Kikuzaki, H., M. Hisamoto, K. Hirose, K. Akiyama and H. Taniguchi. 2002. Antioxidants properties of ferulic acid and its related compounds. J. Agric.and Food Chem. 50: 2161-2168.

Kogoya B, 2012. Pandan kelapa hutan papua (Online), Available:" http:// Benn Kogoya.ipb.ac.id//htm 132 Petani Buah Pandan (P. jiulianetii) Dalam Hutan Lindung Desa Ekapame Lanny Jaya Papua”.

Kogoya, B., B. Guritno, Arifin and A.Suryanto. 2014. Bioactive component of pandan's fruits from Jayawijaya Mountains, Papua, Indonesia. IOSR J of Enviro. Sci. Toxic. and Food Tech. (IOSRJESTFT) 8(8) Ver. I: 01-08.

Kusnandar, F. 2010. Kimia Pangan, Komponen Makro. Dian Rakyat, J akarta.

Maisuthisakul, P., M. Suttajit and R. Pongsawatmanit. 2007. Assessment of phenolic content and free radical scavenging capacity of some Thai indigenous plants. Food Chem. 100: 1409-1418.

Mousa,Y.M., D. Gerasopoulos, I. Metzidakis and A. Kiritsakis. 1996. Effect of altitude on fruits and 
oil quality characteristics of "Mastoides" olive, J of The Sci. of Food and Agric. 71: 345-350.

Milliken, W. 1992. Ethnobotany of the Yali of West Papua. Edinburgh. Royal Botanic Garden.

Muchtadi, D. 2012. Pangan Fungsional \& Senyawa Bioaktif. Alfabeta, Bandung.

Ngando, E.G.F., R. Dhouib, F. Carriere, P.H.A. Zollo and V. Arondel. 2006. Assaying lipase activity from oil palm fruit (Elaeis guineensis Jacq.) mesocarp. Plant Physiol. Biochem. 44: 611-17.

Rose, C.J. 1982. Preliminary observation on the Pandanus nut (Pandanus jiulianettii Marteli.). Proceedings of the Second Papua New Guinea Food Crops Conference, Goroka, 14-18 J uly 1980 Port Moresby: Departement of Primary Industry, PNG.

Salvador, M.D., F. Aranda and G. Fregapane. 2001. Influence of fruit ripening on Cornicabra virgin olive oil quality. A study of 4 successive crop seasons, Food Chem.73:45-53.

Sarungallo, Z.L., P. Hariyadi, N.Andarwulan, and E.H.Purnomo. 2015. Characterization of chemical properties, lipid profile, total phenol and tocopherol content of oils extracted from nine clones of red fruit (Pandanus conoideus), Kasetsart J. (Nat. Sci.) 49: $237-250$.

Seneviratne, K.N., C.D. Hapuarachchi and S. Ekanayake. 2009. Comparison of the phenolicdependent antioxidant properties of coconut oil extracted under cold and hot conditions. Food Chem. 114: 1444-1449.

Servili, M., and G.F. Montedoro. 2002. Contribution of phenolic compounds to virgin olive oil quality. Eur. J . Lipid Sci. Tech. 104: 602-613.

SNI (Indonesian National Standard). 2006. Palm oil. SNI 01-2901-2006. Badan Standarisasi Nasional Indonesia. J akarta. [in Indonesian].

SNI (Indonesian National Standard). 2012. Cooking palm oil. SNI 7709-2012. Badan Standarisasi Nasional Indonesia. J akarta. [in Indonesian].

Stone, B.C. 1982. New Guinea Pandanaceae. First approach to ecology and biogeography. In: Gressitt. J.L (ed). Biogeography and Ecology of New Guinea. Vol.1 Monograhiae Biologicae 42. The Hague: Dr. W. J unk Publ. 